reach where the stream bed is almost level, and it was hoped that the dam would have the effect of containing a large quantity of water beneath the sand, where the animals can be trusted to dig in case of need. Biton Balandow reports that these dams are serving their purpose and a big drive is to be made during the coming dry season to construct as many other dams as is possible with the funds available.

\title{
THE NYIKA PLATEAU, NYASALAND
}

\section{By J. C. Cater}

So little is known about the Nyika plateau that even the observations of an amateur may be of use in reaching a better understanding of this wonderful stretch of mountain country. I first visited the Nyika in 1950 and returned the following year with two colleagues, to investigate forestry possibilities. In July, 1952, we opened a camp and started a forestry pilot scheme. Our work has given us an exceptional opportunity to watch the game and study the flora and climate. Our camp, some $3 \frac{1}{2}$ miles south-east of Kaulime Pond, is at an altitude of r,700 feet and stands in typical short-grass country near the headwaters of Chelinda River.

C. W. Benson has given the area of the Nyika plateau as 1,400 square miles, but the area of the grasslands is considerably less, probably in the vicinity of 500,000 acres. Unfortunately there is no accurate map of the plateau, and only about half of it has been covered by aerial photography. Most of the short-grass area lies between 7,000 and 8,000 feet, but there are many hills rising above 8,000 feet; the highest point, Nganda, is just over $\mathbf{9 , 0 0 0}$ feet. It is very noticeable that the topography of the western half of the plateau is gentler than the eastern half, the dividing line being the watershed that runs south from Nganda to Chejara. North of Nganda the ground falls steeply several thousand feet and, for about 12 miles, the vegetation is Brachystegia woodland, until the grasslands of Kawoza Peaks are reached.

The Nyika is surprisingly cold, even in summer, At our camp the highest shade temperature recorded in a Stevenson screen over a period of eighteen months was 74 degrees Fahrenheit. November was the warmest month, with a mean maximum temperature of 70 degrees and a mean minimum of $51 \cdot 5$ degrees. The mean annual maximum and minimum temperatures were 64.5 and 46 degrees. Frosts occur from late May until early 


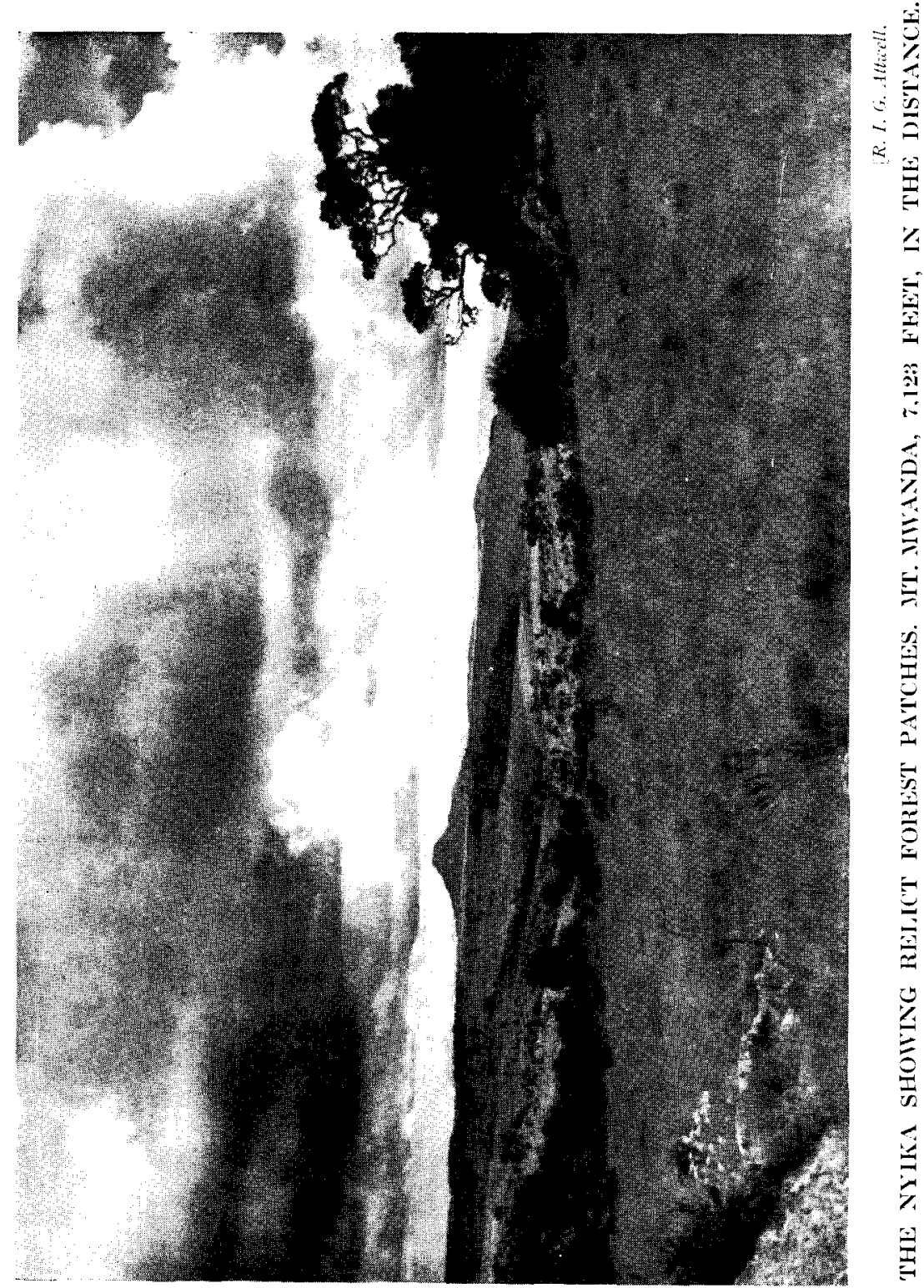


October, but not regularly every night. We have recorded 10 degrees of frost in the Stevenson screen and 18 degrees on the grass in the open. In the valley bottoms the frost is probably a few degrees more severe. The rains appear to break during November and to be over by the end of May, though showers do occur in the other months. Mist-belt conditions do not occur frequently in summer, but during the months June to September the eastern half of the plateau is often covered with cloud down to ground level. Our eleven rain-gauges, dispersed over the plateau, indicate that the annual rainfall is about $\mathbf{4 0}$ inches, but this is based on two wet seasons only, too short a period for any degree of certainty. On the western fringes of the plateau the rainfall is certainly much heavier. There it probably averages about 60 inches, which perhaps accounts for the presence of the best relic patches of forest. Although the prevailing wind throughout the year is easterly most of the rain comes from the west. In summer the storm clouds build up almost daily over the western side of the plateau and sweep eastwards over Kaulime Pond. In winter the winds increase greatly in strength and we have experienced a full gale on several occasions.

There are several hundred patches of relic forest on the Nyika, varying in size from about 50 acres to a few trees doomed to death from fire in a year or two. Until recently a " noburning" policy resulted in very destructive fires late in the year, but this year official policy has returned to the early fires of June and July, which seem to have been normal for many years in the past and which are much less destructive. Nevertheless, any fire gradually eats its way into these mesophytic woods, which have little resistance. Unfortunately the Nyika is extremely vulnerable, for there are many valleys up which fire can come from the lowlands, and once a fire has started the whole Nyika is usually burnt. The Nyika on fire is an awe-inspiring and tragic sight.

It is fascinating to speculate on what vegetation preceded the present grasslands. One can find patches of forest in all parts of the Nyika, though the majority are now confined by fires to the wet valleys. Possibly the temperate evergreen montane forest began in the last glacial period, but, as the climate became drier, conditions were less favourable for its survival. Its disappearance may have been due both to the human element and to the effect of fires started by lightning. We have ourselves twice seen lightning start grass fires. With a drier climate the Juniperus procera forest may have covered a very large part of the Nyika, but as juniper can be wiped out by a few forest fires, 
one wonders how long ago the main deforestation of the Nyika took place.

There is not a great deal of game on the Nyika, but what there is can easily be seen. On 3rd and 4th April Mr. R. I. G. Attwell and $I$ counted 72 eland, 85 roan, 113 zebra, 4 warthog, 3 red duiker, and 7 reed buck. There are probably about 350 eland, 200 zebra, and 150 roan on the whole plateau. Reedbuck are scarce-those we saw were the common, not the mountain reedbuck. A pair of hartebeest have been seen and, six months ago, two buffaloes. There are a few bushbuck and oribi and also, in the forest patches, blue duiker and blue monkey.

Now and then a pride of lions will spend two or three weeks on the Nyika, but do not appear to live there permanently.

Leopards are rare on the short grasslands but are fairly frequent among the rocks and long grass on the western side. Jackals, of two species, are all too numerous, but we have only seen one hyaena. Wild dogs are often seen and on two occasions have chased reedbuck through our camp. Neither we nor our boys have ever seen or heard of sable on the Nyika and it seems possible that one of the solitary, dark-coated roan bulls, of which there are a good dozen individuals with good heads, may have been mistaken for a sable. We have never seen a cheetah but several serval cats have been observed.

Elephant, it seems, used to frequent or at least cross the Nyika. 'There is a clump of forest at an elevation of 7,500 feet known as Zovu yachipolwe, which means "the elephant of Chipolwe " and commemorates the shooting of an elephant there. My men tell me that this took place thirty-five or forty years ago, one of them actually seeing the tusks taken from the elephant. Apparently nobody has seen an elephant there since, but they still occur at Katumbi, only a score of miles away.

It is obvious that the herds of game are deficient in the younger age-classes and possible that the larger kinds have been reduced below the point at which they can survive unaided. They appear to be exposed to two major dangers. The first is their habit, or at least the habit of some of them, of migrating during the worst of the winter from the short grasslands to the Brachystegia woodlands, where they are very liable to poaching. During the winter months there is definitely less game on the plateau and we constantly see both roan and eland near the road in the Brachystegia. The second danger is the wild dog. The Nyika is perfect hunting country for wild dog, and whatever their effect on the larger antelope may be, it seems certain that they are responsible for the scarcity of small buck. Are they, 
perhaps, responsible for the paucity of young eland and roan? It is a remarkable fact that although after the annual grass fires one can see anything lying on the ground, we have only once found a game skeleton, and that was an eland that had obviously been shot near the Nyika Road. Where do the game die ? It seems likely that most of the annual crop of calves is killed while the game is down in the Brachystegia. If the wild dog is mainly responsible, then it seems essential that their numbers should be reduced, and soon.

In many parts of the Nyika one sees troughs made by the game for a purpose which we have not been able to discover. These troughs are about 4 to 5 feet wide and some 15 to 25 yards long. The long axis is invariably at right-angles to the contour and the surface soil has been dug out to a depth of 4 to 8 inches. Often at the lower end there is a circular saucer, of the kind made by game to dust in, and one or more game tracks lead to the trough. Since the soils of the Nyika are practically uniform throughout, being derived from syenite, it seems unlikely that these troughs are salt licks, particularly as the soils are markedly deficient in salts. The attraction of Kaulime Pond and the other small pans in the dry scason is possibly due to the concentration of certain salts in the water as it dries up. The game show a marked preference for the pond water, although the Nyika is abundantly supplied with perennial streams, and one herd of roan spends a large part of the winter days lying in and around Kaulime Pond.

Until recent years it was the practice of the Phoka Africans, who live in the sub-Nyika valleys, where they cultivate wheat, maize, and beans, to hunt game on the Nyika. Their method was to stretch long nets, made from bark rope, between adjoining woods and to drive the game into the nets, where they were despatched by spearmen concealed behind shrubs. It is said that even eland and roan were killed by this means. Old game pits have also been found, usually near the pans. We ourselves have not seen game hunted by Phoka and it is possible that the presence of a government game scout, and of our own camp. has had a discouraging effect.

There are no signs that the short grasslands have ever been inhabited, and since the soils and climate are unsuitable for any of the native food crops it seems unlikely that they ever were. But apart from hunting parties the Nyika was visited by parties of Africans for the purpose of smelting iron. There are traces of their occupation at Chisanga and at Mwajimbula, and recently well-preserved remains were found in and around a small wood 
on the south-western slope of Nganda. Here we found not only the iron ore, a mixture of magnetite and limonite, but some of the iron which the smiths must have overlooked. It appears that the method of smelting was to make a clay hearth, covering it with alternate layers of ore and charcoal, the mound then being covered with clay. Into the bottom of the mound a number of clay pipes, of which many dozen specimens were found, were inserted, and to these were attached the skins of game to form primitive bellows. Lumps of charcoal are still found scattered over a considerable area, indicating that the wood, which now covers less than half an acre, was much larger within relatively recent times; the pit on the bank of the nearby stream, from which the smiths obtained their clay, is still clearly marked. The old ironsmiths may well have made a considerable contribution to the deforestation of the Nyika, a word which in the local tumbuka language means "to burn well".

\section{UGANDA}

\section{(From the 1952 Report of the Game Department.)}

Distribution of revenue from licence fees.-It was decided during the year that African local governments should receive a proportion of the revenue accruing from game licence fees to increase their interest in faunal matters, and thus encourage them to render greater assistance in the preservation of game and the enforcing of the game laws.

Game Assistants.- The creation of the post of game assistants in the General Division of the local Civil Service was approved at the beginning of the year. This post is designed to offer some incentive to game guards, scouts and gun-bearers to better their position and accept greater responsibility. A game assistant will have the opportunity of eventual promotion on merit to assistant game ranger and game ranger.

Elephant Control.- The estimated total elephant wastage for 1952 is approximately 800 which is 600 less than 1951. This figure allows for deaths from natural causes and wastage due to poaching. It is the lowest since full records have been kept and has been due to a drive to reduce unnecessary killing on "control", to the big reduction in the number of elephant licences taken out as a result of the increase in cost per licence, and to the abolition of special licences for third elephant.

The number of elephants killed while protecting crops and cultivation was 477 which is by far the lowest ever recorded 